\title{
Drinking Water from Hand-Pumps in Mali, Niger, and Ghana, West Africa: Review of Health Effects
}

\author{
Alexandra Lutz ${ }^{1 *}$, Samuel Diarra ${ }^{2}$, W. Braimah Apambire ${ }^{1}$, James M. Thomas ${ }^{1}$, Jarvis Ayamsegna ${ }^{2}$ \\ ${ }^{1}$ Division of Hydrologic Sciences, Desert Research Institute, Reno, USA \\ ${ }^{2}$ World Vision West Africa WASH, Accra, Ghana \\ Email: *Alexandra.Lutz@dri.edu
}

Received May 3, 2013; revised June 10, 2013; accepted July 12, 2013

Copyright (C) 2013 Alexandra Lutz et al. This is an open access article distributed under the Creative Commons Attribution License, which permits unrestricted use, distribution, and reproduction in any medium, provided the original work is properly cited.

\begin{abstract}
The purpose of this study was to evaluate parameters of drinking water quality from hand-pumps in Ghana, Mali, and Niger, evaluate possible sources of parameters, and provide an overview of potential health effects in the population. Concentrations of 22 parameters in 3337 groundwater samples were analyzed and compared with World Health Organization drinking water guidelines. In general, F, Mn, and $\mathrm{Al}$ had relatively larger and more common rates of occurrence, though there was by country. For F, there were reports of skeletal fluorosis in Niger and dental fluorosis in Ghana. For $\mathrm{Mn}$ and $\mathrm{Al}$ it was difficult to assess health effects due to scarce information.
\end{abstract}

Keywords: Drinking Water; Groundwater; Water Chemistry; Health

\section{Introduction}

This paper presents data on concentrations of 22 parameters in 3337 groundwater samples from hand pumps in Ghana, Mali, and Niger in West Africa. Samples were grouped by three-country "region" or by individual country. All samples were analyzed for concentrations of $\mathrm{Ag}, \mathrm{Al}, \mathrm{As}, \mathrm{Ba}, \mathrm{Be}, \mathrm{Cd}, \mathrm{Co}, \mathrm{Cr}, \mathrm{Cu}, \mathrm{Fe}, \mathrm{Mn}, \mathrm{Mo}, \mathrm{Ni}, \mathrm{Pb}$, $\mathrm{Sb}, \mathrm{Se}, \mathrm{Sr}, \mathrm{Tl}, \mathrm{U}, \mathrm{V}, \mathrm{Zn}$, and $\mathrm{F}$ with respect to World Health Organization (WHO) drinking water guidelines. The purpose of this study was to evaluate drinking water quality from hand-pumps, assess risk as percent of population exposed, provide overview of human health effects from hand-pump water, and evaluate evidence of these health effects in the population, if available.

Collection and analyses of samples were done in collaboration by World Vision International (WVI) and the Desert Research Institute (DRI) is part of an ongoing effort to provide rural populations with potable water. Samples reported in this study were collected and analyzed between 2002 and 2012. The distribution of sampling points was driven by hand-pump location, which, in turn, was dictated by local need for potable water. Thus, there existed a compromise in sampling for the specific purpose of hypothesis testing, such as analysis of elevated concentrations and geographic trends, or ele-

"Corresponding author. vated concentrations and specific population. Approximate sampling areas are shown in Figure 1.

To-date, several thousand hand-pumps have been commissioned, providing approximately one million rural community members with potable water via this particular project. Across sub-Saharan Africa, however, approximately 880 million people still lack access to safe

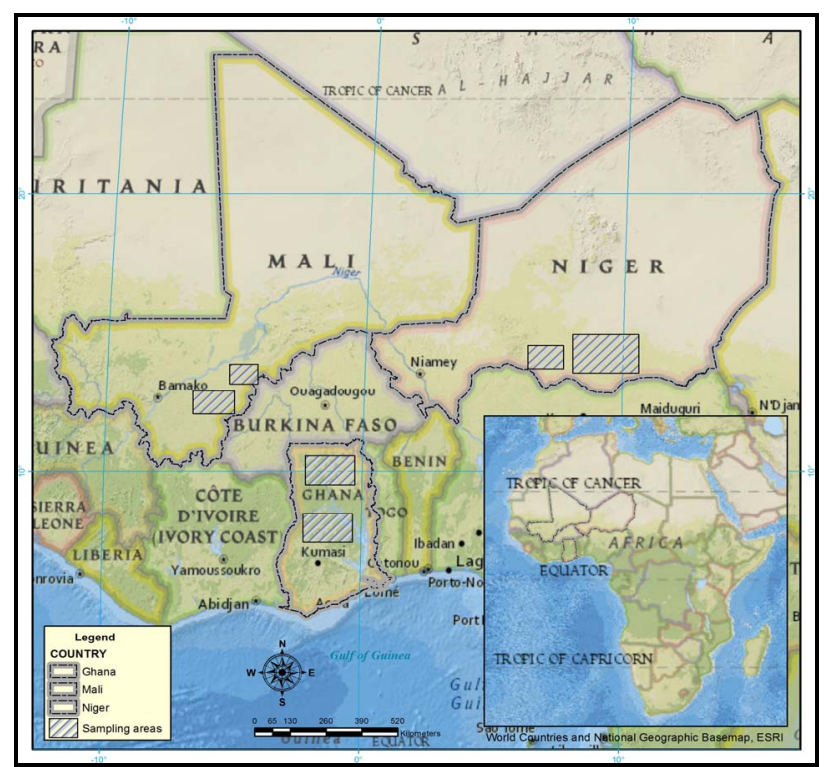

Figure 1. Location of sampling sites. 
drinking water [1]. Groundwater is increasingly relied on as a source of safe drinking water for rural communities in the countries of Ghana, Mali, and Niger in West Africa and elsewhere. Reasons for developing groundwater include ease of developing hand-pumps in remote locations, availability during drought, relative low price compared with methods of treating surface water, and superior chemical and biological quality as compared with surface water sources $[2,3]$.

Though generally considered to be a safer source of drinking water than surface water, groundwater may contain parameters that have either adverse or beneficial effects on human health. Some parameters have typically low concentrations and, in the case of $\mathrm{Co}, \mathrm{Cr}, \mathrm{Cu}, \mathrm{Fe}, \mathrm{I}$, $\mathrm{Mn}, \mathrm{Mo}, \mathrm{Se}, \mathrm{V}$ and $\mathrm{Zn}$, are essential to human life, but at higher concentrations, there may be potential health risks for humans including diseases, disorders, cancers, reduced growth, and increased mortality and mutagenic effects [4]. The effects depend on concentration and a different range of acceptable concentrations existing for each parameter.

To evaluate risk and avoid adverse health effects, WHO drinking water guidelines may be used. These guidelines are derived on the basis of health and internationally agreed procedures for risk assessment [5]. These guidelines are neither regulations nor standards, though they may be used to develop local guidelines or standards on water quality. On the one hand there are guidelines for those considered toxic and for which a relative amount of research has been conducted (As, Fl), while there are no guidelines for those whose effects on human health are not know or unclear (Ag, Be, Co, Sr, and V).

In each country, the water projects seek to supply potable water in rural areas. These areas are characterized by small holder subsistence agriculture, and are generally devoid of industrial activity. While some hot spots may be associated with highly localized cottage industries, parameters in excess of WHO guidelines are largely geologic in origin, naturally occurring, and not likely to be from anthropogenic sources. The distribution of parameters found in the samples, thus, reflects the diverse geological terrains from the three countries.

\section{Methods}

Samples were collected at hand-pumps during borehole development or after drilling but before hand-pump placement. In some cases, samples were collected at actively-used hand-pumps. Samples were collected by staff at Ghana Rural Water Project (GRWP), Mali Rural Water Project (MRWP), and Niger Rural Water Project (NRWP). All water projects are overseen by WVI. After collection, samples were shipped to DRI for analysis. As much as possible, standard methods were applied, however, samples were not field-filtered. Timing was random as sample collection was hampered by monsoonal rains and extreme heat.

Each sample was analyzed for concentrations of 22 parameters. Fluoride was analyzed according to EPA standard methods 4500F [6]. The parameters Ag, Al, As, $\mathrm{Ba}, \mathrm{Be}, \mathrm{Cd}, \mathrm{Co}, \mathrm{Cr}, \mathrm{Cu}, \mathrm{Fe}, \mathrm{Mn}, \mathrm{Mo}, \mathrm{Ni}, \mathrm{Pb}, \mathrm{Sb}, \mathrm{Se}, \mathrm{Sr}$, $\mathrm{Tl}, \mathrm{U}, \mathrm{V}$, and $\mathrm{Zn}$ were analyzed on an inductively coupled plasma-mass spectrometry (ICPMS) according to EPA methods standard methods for drinking water 200.8 [7].

Between 2002 and 2011, detection limits of several parameters analyzed on the ICPMS changed, ultimately becoming lower. Thus, on some figures, previous detection limits will appear as solid lines of data, rather than points. In this study, all data were reported in their originnal format and no efforts were made to adjust, infill, or perform additional measures for values below the detection limit. The results provided are thus reproducible.

\section{Results}

Table 1 shows WHO guidelines for each parameter and percentage of samples exceeding the guidelines. Table 2

Table 1. WHO guidelines and samples exceeding.

\begin{tabular}{|c|c|c|c|c|c|}
\hline \multirow{2}{*}{ Parameter } & \multirow{2}{*}{$\begin{array}{c}\text { WHO } \\
\text { Guideline } \\
(\mu \mathrm{g} / \mathrm{L})\end{array}$} & \multicolumn{4}{|c|}{$\%$ Exceeding Guideline } \\
\hline & & Ghana & Mali & Niger & Region \\
\hline $\mathrm{Ag}$ & NG & NG & NG & NG & $\mathrm{NG}$ \\
\hline $\mathrm{Al}$ & 200 & 5.6 & 8.6 & 5 & 5.9 \\
\hline As & 10 & 6.6 & $*$ & 0.7 & 5.1 \\
\hline $\mathrm{Ba}$ & 700 & 6.6 & 2.1 & 4.2 & 5.8 \\
\hline $\mathrm{Be}$ & NG & NG & NG & NG & NG \\
\hline $\mathrm{Cd}$ & 3 & $*$ & 0.2 & 0.5 & 0.1 \\
\hline $\mathrm{Co}$ & NG & NG & NG & NG & NG \\
\hline $\mathrm{Cr}$ & 50 & $*$ & $*$ & $*$ & * \\
\hline $\mathrm{Cu}$ & 2000 & $*$ & * & * & $*$ \\
\hline $\mathrm{Fe}$ & $\mathrm{NG}$ & $\mathrm{NG}$ & $\mathrm{NG}$ & $\mathrm{NG}$ & $\mathrm{NG}$ \\
\hline $\mathrm{Mn}$ & 400 & 7.5 & 5.6 & 4 & 6.8 \\
\hline Mo & 70 & 2 & * & * & 1.6 \\
\hline $\mathrm{Ni}$ & 70 & $<0.01$ & * & * & $<0.01$ \\
\hline $\mathrm{Pb}$ & 10 & 1.2 & 14.2 & 9.7 & 3.9 \\
\hline $\mathrm{Sb}$ & 20 & $*$ & * & * & $*$ \\
\hline $\mathrm{Se}$ & 10 & 3.7 & 1.6 & 1.7 & 3.2 \\
\hline $\mathrm{Sr}$ & $\mathrm{NG}$ & $\mathrm{NG}$ & $\mathrm{NG}$ & $\mathrm{NG}$ & $\mathrm{NG}$ \\
\hline $\mathrm{Tl}$ & NG & NG & NG & NG & NG \\
\hline $\mathrm{U}$ & 15 & 4.3 & 2.6 & 17.1 & 5.6 \\
\hline $\mathrm{V}$ & NG & NG & NG & $\mathrm{NG}$ & NG \\
\hline $\mathrm{Zn}$ & 5000 & * & * & 0.01 & $<0.01$ \\
\hline $\mathrm{F}(\mathrm{mg} / \mathrm{L})$ & 1.5 & 11.4 & 0.7 & 8.4 & 9.7 \\
\hline
\end{tabular}


Table 2. WHO guideline, mean, median, and range of each parameter.

\begin{tabular}{|c|c|c|c|c|c|c|c|c|c|c|c|c|c|}
\hline \multirow{2}{*}{\multicolumn{2}{|c|}{$\begin{array}{l}\text { WHO guideline } \\
(\mu \mathrm{g} / \mathrm{L})\end{array}$}} & \multicolumn{3}{|c|}{ Ghana } & \multicolumn{3}{|c|}{ Mali } & \multicolumn{3}{|c|}{ Niger } & \multicolumn{3}{|c|}{ Region } \\
\hline & & Mean & Med. & Range & Mean & Med. & Range & Mean & Med. & Range & Mean & Med. & Range \\
\hline $\mathrm{Ag}$ & NG & 0.61 & 1 & $<0.10-14.1$ & 0.9 & 1 & $<0.10-31$ & 0.9 & 1 & $<0.10-1.13$ & 0.7 & 1 & $<0.10-31.5$ \\
\hline $\mathrm{Al}$ & 200 & 67 & 3.06 & $<0.10-7046$ & 68 & 18 & $<0.2-1159$ & 76 & 6 & $0.96-6804$ & 68 & 4.4 & $<0.10-7046$ \\
\hline As & 10 & 2.99 & 1 & $<0.01-122$ & 1.3 & 1 & $<0.01-5$ & 2.4 & 1 & $<0.02-295$ & 2.7 & 1 & $<0.01-295$ \\
\hline $\mathrm{Ba}$ & 700 & 275 & 128 & $<1.0-28,071$ & 174 & 108 & $6.3-3107$ & 185 & 109 & $<1.0-1582$ & 252 & 122 & $<1.0-28,071$ \\
\hline $\mathrm{Be}$ & NG & 0.6 & 1 & $<0.06-22$ & 0.9 & 1 & $<0.06-2.11$ & 1 & 1 & $<0.06-2.39$ & 0.7 & 1 & $<0.06-22$ \\
\hline $\mathrm{Cd}$ & 3 & 0.57 & 1 & $<0.01-2$ & 0.8 & 1 & $<0.01-3.03$ & 0.9 & 1 & $<0.01-5.63$ & 0.6 & 1 & $<0.01-5.63$ \\
\hline Co & NG & 1.13 & 1 & $<0.10-61$ & 1.6 & 1 & $<0.10-21$ & 1.1 & 1 & $<0.10-15.4$ & 1.2 & 1 & $<0.10-61$ \\
\hline $\mathrm{Cr}$ & 50 & 1.31 & 1 & $<0.10-46$ & 1.1 & 1 & $<0.10-10.9$ & 1.3 & 1 & $<0.10-25$ & 1.3 & 1 & $<0.10-45.8$ \\
\hline $\mathrm{Cu}$ & 2000 & 6.8 & 1 & $<0.10-728$ & 2.1 & 1 & $<0.10-21$ & 3.2 & 1 & $<0.10-101$ & 5.8 & 1 & $<0.10-728$ \\
\hline $\mathrm{Fe}$ & NG & 215 & 17.2 & $<0.10-19,244$ & 206 & 28 & $0.61-4943$ & 286 & 20 & $0.64-14,537$ & 223 & 19 & $<0.10-19,244$ \\
\hline $\mathrm{Mn}$ & 400 & 118 & 36 & $<0.10-3683$ & 127 & 37 & $0.68-4998$ & 79 & 12 & $0.41-4023$ & 114 & 33 & $<0.10-4998$ \\
\hline Mo & 70 & 7.39 & 1 & $<0.05-837$ & 1.2 & 1 & $<0.05-28$ & 6.7 & 1 & $<0.05-1546$ & 6.5 & 1 & $<0.05-1546$ \\
\hline $\mathrm{Ni}$ & 70 & 3.32 & 1.36 & $<0.10-388$ & 2.4 & 1.2 & $<0.10-34$ & 1.5 & 1 & $0.11-30$ & 3 & 1.1 & $<0.10-388$ \\
\hline $\mathrm{Pb}$ & 10 & 1.09 & 1 & $<0.10-51.8$ & 14 & 1.9 & $<0.10-649$ & 5.9 & 1 & $<0.10-206$ & 3.3 & 1 & $<0.10-649$ \\
\hline $\mathrm{Sb}$ & 20 & 0.56 & 0.15 & $<0.02-6.74$ & 0.9 & 1 & $<0.02-14.1$ & 0.9 & 1 & $<0.02-1.57$ & 0.7 & 1 & $<0.02-14.1$ \\
\hline $\mathrm{Se}$ & 10 & 7.43 & 1 & $<0.02-11,200$ & 1.9 & 1 & $<0.02-27$ & 2.5 & 1 & $<0.02-29$ & 6.1 & 1 & $<0.02-11,200$ \\
\hline $\mathrm{Sr}$ & NG & 808 & 421 & $<1.0-53,493$ & 304 & 80 & $3.26-11,002$ & 480 & 265 & $<1.0-9339$ & 704 & 326 & $<1.0-53,493$ \\
\hline $\mathrm{Tl}$ & NG & 0.58 & 1 & $<0.03-1.04$ & 0.8 & 1 & $<0.03-10$ & 0.9 & 1 & $<0.03-2.18$ & 0.7 & 1 & $<0.03-10$ \\
\hline $\mathrm{U}$ & 15 & 3.2 & 1 & $<0.10-146$ & 2.4 & 1 & $<0.10-32$ & 12 & 1.1 & $<0.10-355$ & 4.2 & 1 & $<0.10-35.8$ \\
\hline V & NG & 5.27 & 1 & $<0.03-159$ & 1.4 & 1 & $<0.03-28$ & 6 & 2.1 & $<0.03-116$ & 4.9 & 1 & $<0.03-159.2$ \\
\hline $\mathrm{Zn}$ & 5000 & 14.7 & 2 & $<0.10-1822$ & 40 & 7.8 & $0.52-3675$ & 244 & 23 & $0.97-22,042$ & 45 & 3 & $<0.10-22,042$ \\
\hline $\mathrm{F}(\mathrm{mg} / \mathrm{L})$ & 1.5 & 0.73 & 0.32 & $<0.10-14.9$ & 0.2 & 0.1 & $<0.10-3.6$ & 0.5 & 0.2 & $<0.10-10.8$ & 0.6 & 0.3 & $<0.10-14.9$ \\
\hline
\end{tabular}

shows the WHO guideline, mean, median, and range of each parameter. In most cases, minimum values were the detection limits. Both tables show samples grouped by region and individual country.

When viewed by region, $\mathrm{F}$ had the largest occurrence, with $9.7 \%$ of samples exceeding the guideline. The next largest numbers exceeding guidelines were $\mathrm{Mn}, \mathrm{Al}, \mathrm{Ba}, \mathrm{U}$, and As (6.8, 5.9, 5.8, 5.6, and 5.1\%, respectively). Guidelines were exceeded for $\mathrm{Cd}, \mathrm{Mo}, \mathrm{Ni}, \mathrm{Pb}, \mathrm{Se}$, and $\mathrm{Zn}$ for $3.9 \%$ or less of all samples. For these elements and F, mean values were larger than median values, which indicated some unusually high values in the data set. For instance, the mean and median values for Ba were 252 and $122 \mu \mathrm{g} / \mathrm{L}$, with a maximum value of $28.071 \mu \mathrm{g} / \mathrm{L}$.

When viewed by country, $F$ exceeded the guideline for $11.4 \%$ of samples in Ghana. The next largest numbers exceeding guidelines were $\mathrm{Mn}, \mathrm{As}, \mathrm{Ba}$, and $\mathrm{Al}(7.5,6.6$, 6.6 , and $5.6 \%$, respectively). Guidelines were also exceeded for $\mathrm{Mo}, \mathrm{Ni}, \mathrm{Pb}, \mathrm{Se}$, and $\mathrm{U}$, though at rates $4.3 \%$ or less. For these parameters, mean values were larger than median values.

In Mali, $\mathrm{Pb}$ exceeded the guideline for $14.2 \%$ of samples. The next largest numbers were $\mathrm{Mn}$ and $\mathrm{Al}$ (8.6 and
$5.6 \%$, respectively). Guidelines were also exceeded for $\mathrm{Ba}$, $\mathrm{Cd}, \mathrm{Se}, \mathrm{U}$, and $\mathrm{F}$ at rates $2.6 \%$ or less. With the exception of $\mathrm{Cd}$, mean values were larger than median values.

In Niger, $U$ exceeded the guideline for $17.1 \%$ of samples. The next largest numbers were $\mathrm{Pb}, \mathrm{F}$, and $\mathrm{Al}(9.7 \%$, $8.4 \%$, and $5.0 \%$, respectively). Guidelines were also exceeded for $\mathrm{As}, \mathrm{Ba}, \mathrm{Mn}, \mathrm{Se}$, and $\mathrm{Zn}$ at rates $4.2 \%$ or less. With the exception of $\mathrm{Cd}$, mean values were larger than median values.

\section{Discussion}

\subsection{Potential Sources}

Project emphasis was on safe supply of potable water in rural areas, which were characterized by smallholder subsistence agriculture and generally devoid of industrial activity. While some "hot spots" of water chemistry may be associated with highly localized cottage industries, parameters in excess of WHO guidelines were largely geologic in origin and unlikely to have originated from anthropogenic sources.

In Ghana and Niger, for instance, occurrence of $F$ was related to weathering of granitic rocks. In Ghana, As was 
likely released from iron oxides under reducing conditions, which may also explain the occurrence of $\mathrm{Mn}$ [8]. Under reducing conditions, release of As from iron hydroxides may also be bacterially mitigated [9]. Oxidizing, alkaline conditions in Niger may be associated with release of $\mathrm{Pb}$ and $\mathrm{U}$ from urano-carbonate compounds [10]. Values of $\mathrm{pH}$ both higher and lower than neutral (pH 6 to 8) solubilize $\mathrm{Al}$ into groundwater.

Hydraulic conductivity values may impact on groundwater chemistry [9]. For instance, groundwater residence times and subsurface geological formations may suggest high value parameters to have been released from one zone and transported to another. Site characteristics, such as values of $\mathrm{pH}$, redox, hydraulic conductivity, and local geology, may further identify potential sources of high value parameters were not available for the samples presented in this study. The distribution of parameters found in the samples, thus, reflects the diverse geological terrains from the three countries.

\subsection{Potential Health Effects}

The following seven parameters exceeded guidelines for at least $4 \%$ of samples: $\mathrm{Al}, \mathrm{As}, \mathrm{Ba}, \mathrm{Mn}, \mathrm{Pb}, \mathrm{U}$, and $\mathrm{F}$. Human health effects are discussed below. Discussion begins with $\mathrm{F}, \mathrm{Mn}$, and $\mathrm{Al}$, which had relatively larger and more common rates of occurrences. Discussion includes evidence for human health effects and comparisons with other surveys done in similar areas of this study, if available.

There is epidemiological evidence that $\mathrm{F}$ in excess of the WHO guideline carries increasing risks of fluorosis of the enamel (mottling of the teeth) and, at progressively higher concentrations, leads to increasing risks skeletal of skeletal fluorosis $[11,12]$. Guidelines were exceeded in $11.4 \%$ of samples from Ghana, $0.7 \%$ from Mali, $8.4 \%$ from Niger, and the highest maximum value of 14.9 $\mathrm{mg} / \mathrm{L}$ was observed in Ghana. Figure 2 shows cumulative distribution as percentage of $\mathrm{F}$ in Ghana and Niger. Mitigation measures for high $\mathrm{F}$ levels are being taken by GRWP in Ghana and NRWP in Niger.

There is relatively more information available as to health effects and occurrence of $F$ in drinking water as compared with other parameters evaluated in this study, especially in Ghana. Rossiter et al. [1] reports $6.7 \%$ of samples exceeded the guideline, with rates increasing to $17 \%$ in particular regions of Ghana. Apambire et al. [13] reports $62 \%$ of the total population of school children in the Bongo area of Ghana showing dental fluorosis. Both studies suggest high concentrations of $\mathrm{F}$ to be localized.

Ayoob and Gupta [14] describe both Niger and Ghana as places where fluorosis is endemic. More specifically, 425 cases of children with skeletal fluorosis are reported in Tibiri, Niger; drinking water samples from the area showed 4.8 to $6.6 \mathrm{mg} / \mathrm{L}$ of F [15]. Relatively less infor-

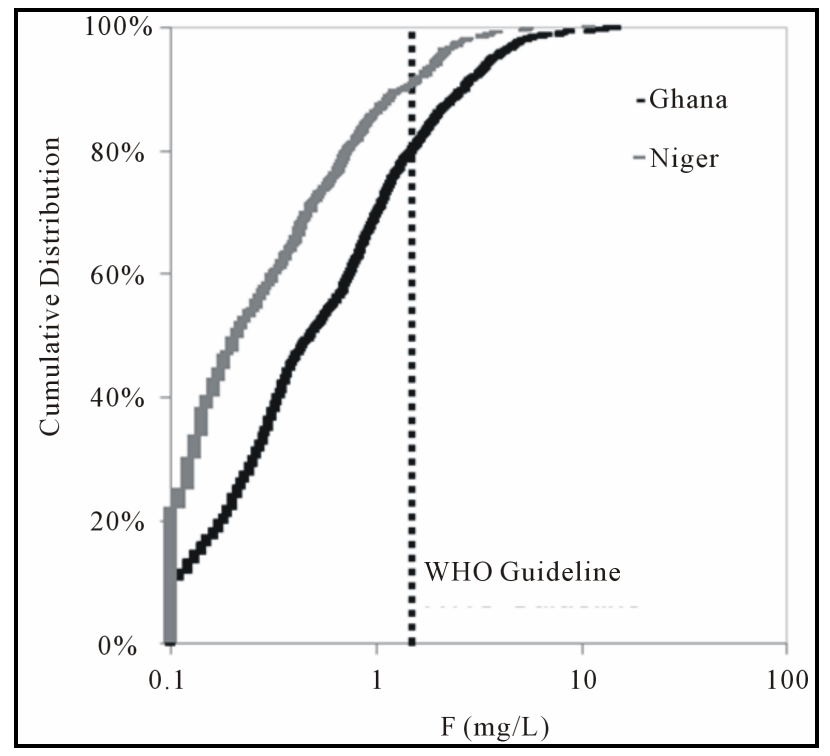

Figure 2. Cumulative distribution as percenatge of fluoride samples from Ghana and Niger.

mation on exposure is available from Mali. One study reports $\mathrm{F}$ ranging from $<0.2$ to $1.7 \mathrm{mg} / \mathrm{L}(\mathrm{n}=19)$, with only one sample above the guideline [16]. In a geologically-based model of F occurrence above WHO guidelines, Amini et al. [17] predict probability increasing from close to $0 \%$ to $80 \%$ in Mali and Niger along southwest to northeast axes in both countries.

Epidemiological studies show exposure to $\mathrm{Al}$ and $\mathrm{Mn}$ to be risk factors associated with mental impairment. Specifically, $\mathrm{Al}$ is associated with the development or acceleration of onset of Alzheimer's disease [18]. Exposure to $\mathrm{Mn}$ is associated with intellectual impairment in children. Studies link levels of Mn greater than 1000 $\mu \mathrm{g} / \mathrm{L}$ in drinking water with: child attention and memory impairments, impaired manual dexterity and speed, and neurological symptoms including a repetitive stuttered, speech, poor balance, coordination, and fine motor skills [19]. The Al guideline was exceeded in $5.6 \%$ of samples from Ghana, 8.6\% from Mali, and 5.0\% from Niger (Figure 3). In Ghana, high concentrations of Al (mean value 4455 $\mu \mathrm{g} / \mathrm{L}, \mathrm{n}=60$ ) in groundwaters were reported to be localized [20]. A review of chemical water quality from 230 boreholes, wells, and standpipes of different regions in Ghana reported $95 \%$ of samples had $\mathrm{Al}$ above the guideline value, in particular in the Volta Region [1]. The localized nature of $\mathrm{Al}$ occurrence may explain why relatively fewer samples were in excess of the WHO guideline in this study, which evaluated only hand pumps and sampled a larger geographical area. No similar studies as to $\mathrm{Al}$ concentrations in Mali or Niger were found.

The guideline for $\mathrm{Mn}$ was exceeded in $7.5 \%$ of samples from Ghana, 5.6\% from Mali, and 4.0\% from niger (Figure 4). Rossiter et al. [1] report $\mathrm{Mn}$ to be 


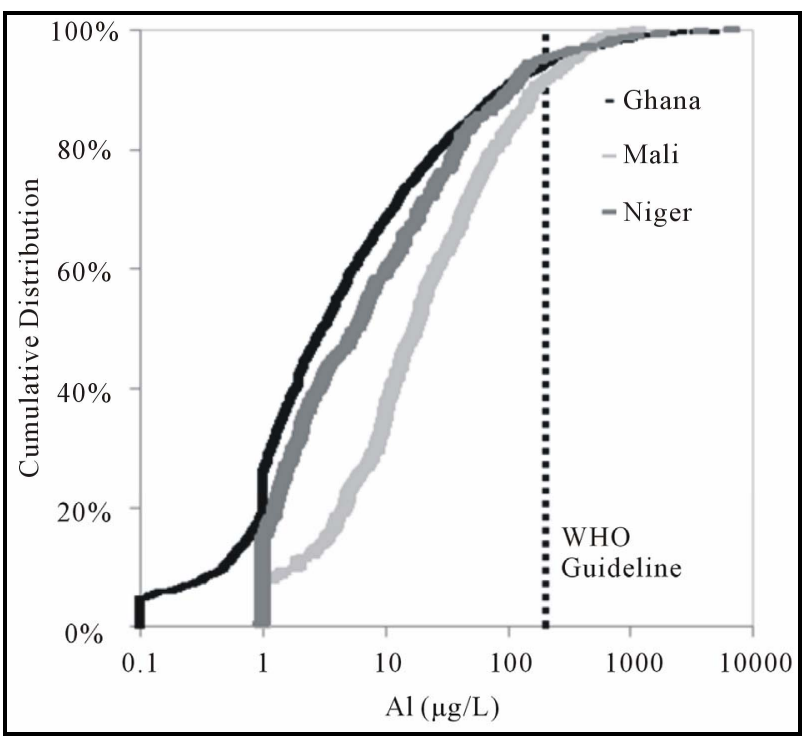

Figure 3. Cumulative distribution as percenatge of aluminum samples from Ghana, Mali, and Niger.

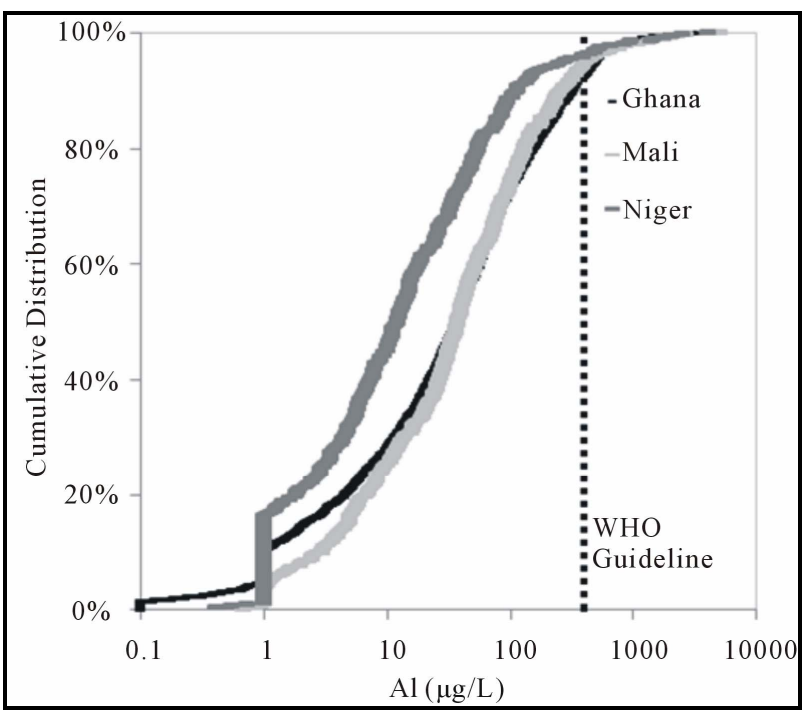

Figure 4. Cumulative distribution as percenatge of aluminum samples from Ghana, Mali, and Niger.

one of the most widespread parameters in Ghana, exceeding the WHO guideline in $11 \%$ of samples from that study. No studies as to Mn concentrations in boreholes from Malior Niger were found.

It is difficult to evaluate rates of mental impairment resulting from exposure from drinking water with few drinking water data and without a baseline of mental health. In general, there is little information as to mental health disorders and rates of diagnoses in developing countries. A general survey of mental health services in 185 developing countries (including Ghana) reports a scarcity of available resources relative to the populationlevel need, chronic shortages of trained personnel, shortfalls between the total health expenditure and those for mental health, and incomplete mental health policy frameworks [21,22].

Even with a baseline of mental health, the underlying cause may be difficult to determine. Severe malnutrition during childhood can lead to impaired psychological, intellectual, and motor skill development, ultimately leading to functional impairment [23]. Percentages of the under-five population characterized as moderately and severely underweight are: $14 \%$ in Ghana, $27 \%$ in Mali, and $40 \%$ in Niger [24]. Rates of wasting, which is defined as being two standard deviations below the median height-for-weight of the WHO child growth standards, are: $9 \%$ in Ghana, $15 \%$ in Mali, and $16 \%$ in Niger [24].

Heavy metals such as $\mathrm{As}, \mathrm{Pb}$, and $\mathrm{U}$ are associated with DNA damage, cancers, and damage to the central nervous system [2,5]. Relatively more information is available for health effects of As in drinking water than for some of the other parameters discussed in this study. Drinking water contaminated with arsenic is a major public health problem reported in many countries of the world [11]. Epidemiological studies show that long-term consumption of elevated levels of As in drinking water is directly related to increased cancers, skin ailments, neurological disorders, and type 2 diabetes [2,5]. In children, exposure to As from drinking water is associated with intellectual impairment [19].

Arsenic exceeded the guideline in $6.6 \%$ of all samples from Ghana, none from Mali, and $0.7 \%$ from Niger. Mitigation measures for high As levels are being taken by GRWP in Ghana. Other studies in Ghana report guidelines exceeded for less than $2 \%$ of samples and occurrence to be localized [1,25]. Pelig-Ba et al. [26] reports no arsenic from boreholes $(\mathrm{n}=33)$. Few data are available for Mali and Niger, but a global model predicting As in groundwater shows probabilities of occurrence as: none for Niger, up to $50 \%$ for localized areas of Mali and Ghana, and up to $100 \%$ for localized areas of Ghana [27].

Though $U$ is deposited at bone surfaces, where alpha radiation is emitted, risks arising from the biochemical toxicity of $U$ as a heavy metal are considered to be about six orders of magnitude higher than those deriving from its radioactivity [28]. The guideline for $\mathrm{Pb}$ was exceeded for $1.3 \%$ of samples from Ghana, $14.2 \%$ from Mali, and 9.7\% from Niger; the guideline for $U$ was exceeded for $4.3 \%$ of samples from Ghana, $2.6 \%$ from Mali, and $17.1 \%$ from Niger.

In Ghana, $\mathrm{Pb}$ and $\mathrm{U}$ exceeding WHO guidelines are attributed to mining activities [1]. In one area, high $\mathrm{Pb}$ and $\mathrm{Cr}$ was attributed to use of agro-chemical [29]. Concentrations of $\mathrm{Pb}$ were reported "occasionally" exceeding the guideline [20,30] or not exceeding it at all [25]. The French NGO, CRIIRAD, reported water and soil from mine areas in Niger to be contaminated with dangerously high radioactivity levels [31], though values and 
numbers of samples were not given. In general, limited water quality data are available for these parameters in Mali and Niger.

It is difficult to evaluate rates of cancers directly resulting from exposure from drinking water. Detailed information as to rate, type, and survival of cancer in developing countries is scarce. A global review of cancer rates estimated that cancer rates in developed countries are twice those of developing countries with the discrepancy, in part, attributed to risk factors, diagnosis, and treatment [32]. In order of estimated rate of diagnosis in developing countries are: lung, stomach, and liver for men; and breast, cervix/uterus, and lung for women [32]. The National Cancer Registry in the Gambia shows liver cancer to be the most common cancer among men $(62 \%)$ and second-most common cancer among women ( $28 \%$ following cervical cancer, which is $29 \%$ ), with occurrence attributed to prevalence of chronic hepatitis in the population [33].

Finally, Barium at levels above the guidelines may increase the risk of hypertension, but neither mutagenic not carcinogenic impacts are reported in the literature [2]. Barium exceeding the guidelines was found in $6.6 \%$ of samples from Ghana, 2.1\% from Mali, and $4.2 \%$ from Niger. In Ghana, reported concentrations of Ba in groundwater (mean value $125.3 \mu \mathrm{g} / \mathrm{L}, \mathrm{n}=60$ ) and localized [20]. No similar studies as to Al concentrations in Mali or Niger were found.

\subsection{Caveats}

Several caveats are noted for this study. Twelve parameters exceeded WHO drinking water guidelines. While exposure to any of these parameters including $\mathrm{Cd}$, Mo, $\mathrm{Ni}, \mathrm{Se}, \mathrm{Zn}$, is not trivial, the impact on human health of less-frequently-occurring parameters may be outweighed by reduction of water-related infectious diseases from microbially contaminated surface water [2]. As an example, the prevalence of liver cancer due to water-borne hepatitis may be reduced if alternative water sources are available to the population of The Gambia.

Another consideration is that most drinking water quality studies referencing these guidelines (including this one) focus on the amount of a parameter that is ingested in water rather than total exposure [12], multiparameter effects, and likely underestimate the amount of water consumed in very hot, arid climates. Multi-parameter effects, either adverse or beneficial, are unclear. For example, As toxicity is aggravated by $\mathrm{Sb}$, and $\mathrm{As}$ increases toxicity of $\mathrm{Ni}, \mathrm{Cd}, \mathrm{Co}$, and $\mathrm{Cr}$ to where the $\mathrm{WHO}$ guideline should be $1 / 20$ of the suggested value; conversely, toxicity of As may be reduced by intake of Se and $\mathrm{Zn}$, though in amounts beyond those typically occurring in drinking water alone [2].

In this study, no samples exceeded Sb guidelines, and restricting criteria to where As exceeded the guideline and $\mathrm{Sb}$ exceeded the detection limit yielded seven samples, all from Ghana. Overall, number of samples exceeding guidelines for $\mathrm{Ni}$ was less than 0.01 and less than $1 \%$ for $\mathrm{Cd}$. No samples exceeded guidelines for $\mathrm{Cr}$ and there are no guidelines for Co. Restricting criteria to where As exceeded the guideline and $\mathrm{Ni}$ was $1 / 20$ of the guideline value $(3.5 \mu \mathrm{g} / \mathrm{L})$ yielded 78 samples, all from Ghana. This exercise could not be done for $\mathrm{Cd}$, as $1 / 20$ of the $3 \mu \mathrm{g} / \mathrm{L}$ WHO drinking water guideline is below the detection limit. Restricting criteria to where As exceeded the guideline and $\mathrm{Cr}$ was $1 / 20$ of the guideline value (2.5 $\mu \mathrm{g} / \mathrm{L}$ ) yielded 15 samples, all from Ghana.

With respect to mitigating toxicity, the highest value of $\mathrm{Zn}$ in a sample with As exceeding the guideline was $697 \mu \mathrm{g} / \mathrm{L}$. Depending on water intake, other food sources, and weight of the consumer, the WHO recommended daily intake value of $\mathrm{Zn}$ of $15 \mathrm{mg}$ may or may not be met. The latter is more likely. Restricting criteria to where both As and Se exceeded the guideline yielded 23 samples, all from Ghana. The WHO recommended daily intake value of Se is $60 \mu \mathrm{g} / \mathrm{kg}$ for women and $70 \mu \mathrm{g} / \mathrm{kg}$ for men. As with Zn, meeting the daily intake of Se will depending on other sources. This finding supports the notion that there is not likely to be enough $\mathrm{Zn}$ in drinking waters to reduce toxicity of As.

Countries with very hot climates and high incidence of fluorosis, such as China and India, have established stricter standards than the WHO. The Chinese and Indian standards for fluoride in drinking water are less than 1 and $1.2 \mathrm{mg} / \mathrm{L}$, respectively [34,35]. In determining the optimal fluoride concentration in drinking water for South India, Viswanathan et al. [36] considered average amounts of drinking water, tea or coffee, and food consumed and determined maximum fluoride concentration should be $0.5 \mathrm{mg} / \mathrm{L}$, one third of the WHO guideline. In a similar study in northern Ghana, Apambire [37] used climate data to estimate the optimum concentration for fluoride in drinking water to be 0.4 to $0.6 \mathrm{mg} / \mathrm{L}$.

It is noted that establishing, and amending, drinking water guidelines is difficult for a number of reasons. Data on human health effects are collected from studies carried out laboratory animals and the human population. Results of laboratory studies using high doses of an element on animals yields uncertainty as to the actual effects on human health. Results of population studies are complicated by duration of studies (on the order of decades), scarce information regarding exposure rates, simultaneous presence of other toxic agents, and the fact that some trace elements cause adverse effects only after extended exposure (years rather than months). In general, exhaustive data on health effects are often simply not available. As an example, underlying causes of mental health disorders are difficult to determine under the best of circumstances with respect to clean drinking water and 
proper nourishment.

\section{Conclusions}

The purpose of this study was to evaluate drinking water quality, assess risk as percent of population exposed to parameters, provide overview of human health effects, and evaluate evidence of health effects of drinking water quality in the population, if available. When risk was evaluated by three-country region, $\mathrm{F}$ was the most widespread parameter $(9.7 \%)$ followed by: $\mathrm{Mn}, \mathrm{Al}, \mathrm{Ba}, \mathrm{U}$, and As. In Ghana, $\mathrm{F}$ was the most widespread parameter (11.4\%) followed by: $\mathrm{Mn}, \mathrm{As}, \mathrm{Ba}, \mathrm{Al}$, and $\mathrm{U}$. In Mali, Pb was the most widespread parameter, followed by $\mathrm{Al}$ and Mn. In Niger, $U$ was the most frequent parameter (17.1\%) followed by $\mathrm{Pb}, \mathrm{Al}, \mathrm{Ba}$, and $\mathrm{Mn}$.

An overview and evidence of health effects depended on the parameter, with relatively more information available for some parameters than for others. For F, for instance, there are reports of skeletal fluorosis in Niger and dental fluorosis in Ghana. For Mn and Al, it is difficult to assess mental health due to lack of baseline data and other underlying causes such as childhood malnourishment. For other heavy metals, including $\mathrm{Pb}, \mathrm{U}$, and $\mathrm{As}$, it is difficult to quantify rates of cancers water directly related to exposure from drinking water; detailed information as to rate, type, and survival of cancer in developing countries is scarce.

In general, $\mathrm{F}, \mathrm{Mn}$, and $\mathrm{Al}$ had relatively larger and more common rates of occurrence and mitigation measures should be carefully considered. Exposure to other parameters including $\mathrm{As}, \mathrm{Pb}$, and $\mathrm{U}$ is not trivial and the risks to community members should also be considered. Evidence suggests that many of the parameters may be localized; detailed geological and geochemical mapping is crucial to understand water-rock interactions and, in turn, identify areas of higher risk. It is anticipated that information from this study may be used to support water resources management, borehole drilling activities, and planning process of new drinking water projects. This is particularly important as the demand for drinking water from groundwater is expected to increase.

\section{Acknowledgements}

The authors wish to thank field staff and the various communities in which sampling took place. Funding for the project was provided, in part, by the Conrad N. Hilton Foundation.

\section{REFERENCES}

[1] H. Rossiter, P. Owusu, E. Awuah, A. Macdonald and A. Schäfer, "Chemical Drinking Water Quality in Ghana: Water Costs and Scope for Advanced Treatment," Sci- ence of the Total Environment, Vol. 408, No. 11, 2010, pp. 2378-2386. doi:10.1016/j.scitotenv.2010.01.053

[2] J. Buschmann, M. Berg, C. Stengel, L. Winkel, M. Sampson and P. Trang, "Contamination of Drinking Water Resources in the Mekong Delta Floodplains: Arsenic and Other Trace Metals Pose Serious Health Risks to Population," Environment International, Vol. 34, No. 6, 2008, pp. 756-764.

[3] P. Gyau-Boakye, "Sources of Rural Water Supply in Ghana," Water International, Vol. 26, No. 1, 2008, pp. 96-104.

[4] W. Edmunds and P. Smedley, "Groundwater Geochemistry and Health: An Overview," In: J. Appleton, R. Fuge and G. McCall, Eds., Environmental Geochemistry and Health, Geological Society of London, London, 1996, pp. 91-105.

[5] World Health Organization, "Guidelines for Drinking Water Quality," 2011.

http://www.who.int/water_sanitation_health/publications/ 2011/dwq_guidelines/en

[6] United States Environmental Protection Agency, "Standard Methods for the Examination of Water and Wastewater," 18th Edition, United States Environmental Protection Agency, Washington DC, 1992.

[7] United States Environmental Protection Agency, "Methods for the Determination of Metals in Environmental Samples Supplement 1,” 2012. http://www.nemi.gov

[8] P. Smedley and D. Kinniburgh, "A Review of the Source, Behaviour, and Distribution of Arsenic in Natural Waters," Applied Geochemistry, Vol. 17, No. 5, 2002, pp. 517-568. doi:10.1016/S0883-2927(02)00018-5

[9] C. Dowling, R. Poreda, A. Basu and S. Peters, "Geochemical Study of Arsenic Release Mechanisms in the Bengal Basin Groundwater," Water Resources Research, Vol. 38, No. 9, 2002, pp. 12-1-12-8.

[10] P. Smedley, J. Knudsen and D. Maiga, "Arsenic in Groundwater from Mineralised Proterozoic Basement Rocks of Burkina Faso," Applied Geochemistry, Vol. 22, No. 5, 2007, pp. 1074-1092. doi:10.1016/j.apgeochem.2007.01.001

[11] J. Bunnell, R. Finkelman, J. Centeno and A. Selinus, "Medical Geology: A Globally Emerging Discipline," Geologica Acta, Vol. 5, No. 3, 2007, pp. 273-281.

[12] J. Fawell, K. Bailey, J. Chilton, E. Dahi, L. Fewtrell and Y. Magara, "Fluoride in Drinking water," World Health Organisation, Geneva, 2006.

[13] W. Apambire, D. Boyle and F. Michael, "Geochemistry, Genesis and Health Implications of Fluoriferous Groundwater in the Upper Regions of Ghana," Environmental Geology, Vol. 35, No. 1, 2007, pp. 13-24.

[14] S. Ayoob and A. Gupta, "Fluoride in Drinking Water: A Review on the Status and Stress Effects," Critical Reviews in Environmental Science and Technology, Vol. 36, No. 6, 2006, pp. 433-487

[15] S. Arji, "Hundreds of Children Poisoned by Tap Water," 2012.

http://www.fluoridealert.org/news/hundreds-of-children-p oisoned-by-tap-water 
[16] British Geological Survey, "Groundwater Quality: Mali," 2012. http://www.bgs.ac.uk/downloads

[17] M. Amini, K. Abbaspour, M. Berg, L. Winkel, S. Hug, E. Hoehn, H. Yang and C. Johnson, "Statistical Modeling of Global Geogenic Arsenic Contamination in Groundwaters," Environmental Science and Technology, Vol. 42, No. 10, 2008, pp. 3669-3675. doi:10.1021/es702859e

[18] P. Ferreira, A. Piai-Kde, A. Takayanagui and S. SeguraMuñoz, "Aluminum as a Risk Factor for Alzheimer's Disease," Revista Latino-Americana Enfermagem, Vol. 16, No. 1, 2008, pp. 151-157.

[19] G. Wasserman, X. Liu, F. Parvez, H. Ahsan, D. Levy and P. Factor-Litvak, "Water Manganese Exposure and Children's Intellectual Function in Araihazar, Bangladesh," Environmental Health Perspectives, Vol. 114, No. 1, 20006, pp. 124-129.

[20] K. Pelig-Ba, "Trace Elements in Groundwater from Some Crystalline Rocks in the Upper Regions of Ghana," Water, Air and Soil Pollution, Vol. 103, No. 1-4, 1998, pp. 71-89. doi:10.1023/A:1004968109028

[21] C. Ferri, D. Chisholm, M. Van Ommeren and M. Prince, "Resource Utilization for Neuropsychiatric Disorders in Developing Countries: A Multinational Delphi Consensus Study," Social Psychiatry and Psychiatric Epidemiology, Vol. 39, No. 3, 2004, pp. 218-227.

[22] World Health Organization, "Atlas: Mental Health Resources in the World 2001," WHO, Geneva, 2001. http://www.who.int/mental health

[23] M. Blössner and M. de Onis, "Malnutrition: Quantifying the Health Impact at National and Local Levels," Environmental Burden of Diseases Series, Vol. 12, No. 12, 2005 , pp. $1-43$.

http://www.who.int/quantifying_ehimpacts/publications/e b12/en/index.html

[24] United Nations International Children's Emergency Fund, "State of the World's Children, 2012," 2012. http://www.unicef.org/sowc2012

[25] British Geological Survey, "Groundwater Quality: Ghana," 2000. http://www.bgs.ac.uk/downloads

[26] K. Pelig-Ba, A. Parker and M. Price, "Trace Elements from the Birrimian Metasediments of the Northern Region of Ghana," Water, Air and Soil Pollution, Vol. 153, No. 1-4, 2004, pp. 69-93. doi:10.1023/B:WATE.0000019933.83346.1d

[27] M. Amini, K. Mueller, K. Abbaspour, T. Rosenberg, M. Afyuni, K. Møller, M. Sarr and A. Johnson, "Statistical
Modeling of Global Geogenic Fluoride Contamination in Groundwaters," Environmental Science and Technology, Vol. 42, No. 10, 2008, pp. 3662-3668. doi:10.1021/es071958y

[28] P. Milvy and R. Cothern, "Scientific Background for the Development of Regulations for Radionuclides in Drinking Water," In: R. Cothern and P. Rebers, Eds., Radon, Radium, and Uranium in Drinking Water, Lewis Publishers, New York, 1990, pp. 1-16.

[29] K. Obiri-Danso, M. Adonadaga and J. Hogarh, "Effect of Agrochemical Use on the Drinking Water Quality of Agogo, a Tomato Growing Community in Ashanti Akim, Ghana," Bulletin of Environment, Contamination, and Toxicology, Vol. 86, No. 1, 2011, pp. 71-77.

[30] K. Pelig-Ba, C. Biney and L. Antwi, "Trace Metal Concentration in Borehole Waters from the Upper Regions and the Accra Plains of Ghana," Water, Air and Soil Pollution, Vol. 59, No. 3-4, 1991 pp. 333-345. doi:10.1007/BF00211841

[31] Author Unknown, "NIGER: Uranium-Blessing or Curse?" 2012.

http://www.irinnews.org/Report/74738/NIGER-Uraniumblessing-or-curse

[32] A. Jemal, F. Bray, M. Center, J. Ferlay, E. Ward and D. Forman, "Global Cancer Statistics," Cancer Journal for Clinicians, Vol. 61, No. 2, 2011, pp. 69-90.

[33] D. Sighoko M. Curado, D. Bourgeois, M. Mendy and P. Hainaut, "Increase in Female Liver Cancer in the Gambia, West Africa: Evidence from 19 Years of PopulationBased Cancer Registration (1988-2006)," PLoS One, Vol. 6, No. 4, 2010, Article ID: e18415.

[34] Q. Ziang, L. Liang, L. Chen, C. Wang, B. Chen, X. Chen and M. Zhou, "Effect of Fluoride in Drinking Water on Children'S Intelligence," Fluoride, Vol. 36, No. 2, 2003, pp. 84-94.

[35] Bureau of India Standards, "India Standards for Drinking Water," Bureau of India Standards, New Delhi, 1992.

[36] G. Viswanathan, A. Jaswanth, S. Gopalakrishnan and S. Siva Ilango, "Mapping of Fluoride Endemic Areas and Assessment of Fluoride Exposure," Science of The Total Environment, Vol. 407, No. 5, 2009, pp. 1579-1587. doi:10.1016/j.scitotenv.2008.10.020

[37] W. Apambire, "Geochemical Modeling and Geomedical Implication of Fluoriferous Groundwater in the Upper Regions of Ghana," Unpublished Dissertation, University of Nevada, Reno, 2000. 